\title{
Induction of G2/M arrest and inhibition of cyclooxygenase-2 activity by curcumin in human bladder cancer T24 cells
}

\author{
CHEOL PARK $^{1 *}$, GI YOUNG KIM ${ }^{2 *}$, GUN DO KIM ${ }^{3}$, BYUNG TAE CHOI $^{4}$, \\ YEONG-MIN PARK ${ }^{5}$ and YUNG HYUN CHOI ${ }^{1,6}$
}

\begin{abstract}
Departments of ${ }^{1}$ Biochemistry, and ${ }^{2}$ Anatomy, Dongeui University College of Oriental Medicine; ${ }^{3}$ Department of Biomaterial Control, Dongeui University Graduate School, Busan 614-052; ${ }^{4}$ School of Applied Marine Science, College of Ocean Science, Cheju National University, Jeju 690-756; ${ }^{5}$ Department of Microbiology, College of Natural Sciences, Kukyong National University, Busan 608-737; ${ }^{6}$ Department of Microbiology and Immunology, and Laboratory of Dendritic Cell Differentiation and Regulation, Pusan National University College of Medicine, Busan 602-739, Korea
\end{abstract}

Received November 1, 2005; Accepted December 21, 2005

\begin{abstract}
Curcumin, a polyphenol compound derived from Curcuma longa Linn, has been recognized as a promising anti-cancer drug due to its multiple properties including antiinflammatory, anti-oxidant and anti-carcinogenic activities. To elucidate the mechanisms by which curcumin inhibits human bladder carcinoma T24 cell proliferation, we tested the effects of curcumin on specific cell cycle pathways and on the expression of cyclooxygenases (COXs). Curcumin inhibited the growth of T24 cells and induced G2/M arrest in a concentration-dependent manner, effects associated with the down-regulation of cyclin A and up-regulation of cyclindependent kinase (Cdk) inhibitor p21 (WAF1/CIP1). However, other $\mathrm{G} 2 / \mathrm{M}$ regulatory molecules, such as cyclin $\mathrm{A}, \mathrm{Cdc} 2$, Cdk2, Wee1 and Cdc25C, were not modulated by curcumin treatment. Furthermore, curcumin decreased the levels of COX-2 mRNA and protein expression without significant changes in the levels of COX-1, which correlated with a decrease in prostaglandin $\mathrm{E}_{2}\left(\mathrm{PGE}_{2}\right)$ synthesis. These observations suggest that curcumin may have therapeutic potential for bladder cancer patients.
\end{abstract}

Correspondence to: Dr Yung Hyun Choi, Department of Biochemistry, Dongeui University College of Oriental Medicine, Busan 614-052, Korea

E-mail: choiyh@deu.ac.kr

Dr Yeong-Min Park, Department of Microbiology and Immunology, Pusan National University College of Medicine, Busan 602-739, Korea

E-mail: immunpym@pusan.ac.kr

${ }^{*}$ Contributed equally

Key words: curcumin, T24 bladder cancer, G2/M arrest, p21, COX-2

\section{Introduction}

Cell cycle checkpoints ensure the maintenance of genomic integrity by protecting dividing cells from the potentially fatal consequences of DNA damage. The detection of DNA damage relies on a cascade of enzymes, conveying the signal(s) generated by different genotoxic stresses that block key cell cycle transitions until DNA repair has occurred (1). In the case of irreparable damage, the cells may be forced to withdraw definitively from the cell cycle or die by apoptosis so that they do not replicate or segregate chromosomes bearing unrepaired lesions. Defects in the DNA damage checkpoint and/or related cell cycle regulation network could contribute to the development of diverse types of mutations or chromosome rearrangements and promote tumorigenesis $(2,3)$.

In experimental studies, induction of cyclooxygenase (COX)-2, the enzyme catalyzing the rate-limiting step in prostaglandin biosynthesis from the substrate arachidonic acid, has been shown to promote cell growth, inhibit apoptosis and enhance cell motility (4). Moreover, compelling evidence from genetic and clinical studies indicates that COX-2 upregulation is a key step in carcinogenesis, and there is a clear positive correlation between COX-2 expression and the inhibition of cell proliferation. Overexpression of COX-2 is sufficient to cause tumorigenesis in animal models, and inhibition of the COX-2 pathway results in a reduction in tumor incidence and progression. Therefore, inhibition of COX-2 activity promises to be an effective approach in the prevention and treatment of cancer (5).

Curcumin is a phenolic compound from the turmeric plant (Curcuma longa Linn, Zingiberaceae) and related species. This compound is widely used as a coloring and flavoring agent in food, and has been shown to exert a wide array of pharmacological and biological activities $(6,7)$. To elucidate a possible mechanism of curcumin, previous studies have focused on the capability of curcumin to inhibit the growth or proliferation of human cancer cells. Curcumin interrupts the cell cycle (most often in $\mathrm{G} 2 / \mathrm{M}$ phase), disrupts the mitotic spindle structure, and induces cell death (including apoptosis 
Table I. Gene-specific primers for RT-PCR.

\begin{tabular}{|c|c|c|}
\hline Name & & Sequence of primers \\
\hline Cyclin A & $\begin{array}{l}\text { Sense } \\
\text { Antisense }\end{array}$ & $\begin{array}{l}\text { 5'-TCC-AAG-AGG-ACC-AGG-AGA-ATA-TCA-3' } \\
\text { 5'-TCC-TCA-TGG-TAG-TCT-GGT-ACT-TCA-3' }\end{array}$ \\
\hline Cyclin B1 & $\begin{array}{l}\text { Sense } \\
\text { Antisense }\end{array}$ & $\begin{array}{l}\text { 5'-AAG-AGC-TTT-AAA-CTT-TGG-TCT-GGG-3' } \\
\text { 5'-CTT-TGT-AAG-TCC-TTG-ATT-TAC-CAT-G-3' }\end{array}$ \\
\hline $\mathrm{Cdc} 2$ & $\begin{array}{l}\text { Sense } \\
\text { Antisense }\end{array}$ & $\begin{array}{l}\text { 5'-GGG-GAT-TCA-GAA-ATT-GAT-CA-3' } \\
\text { 5'-TGT-CAG-AAA-GCT-ACA-TCT-TC-3' }\end{array}$ \\
\hline $\mathrm{Cdk} 2$ & $\begin{array}{l}\text { Sense } \\
\text { Antisense }\end{array}$ & $\begin{array}{l}\text { 5'-GCT-TTC-TGC-CAT-TCT-CAT-CG-3' } \\
\text { 5'-GTC-CCC-AGA-GTC-CGA-AAG-AT-3' }\end{array}$ \\
\hline p53 & $\begin{array}{l}\text { Sense } \\
\text { Antisense }\end{array}$ & $\begin{array}{l}\text { 5'-GCT-CTG-ACT-GTA-CCA-CCA-TCC-3' } \\
\text { 5'-CTC-TCG-GAA-CAT-CTC-GAA-GCG-3' }\end{array}$ \\
\hline $\mathrm{p} 21$ & $\begin{array}{l}\text { Sense } \\
\text { Antisense }\end{array}$ & $\begin{array}{l}\text { 5'-CTC-AGA-GGA-GGC-GCC-ATG-3' } \\
\text { 5'-GGG-CGG-ATT-AGG-GCT-TCC-3' }\end{array}$ \\
\hline p16 & $\begin{array}{l}\text { Sense } \\
\text { Antisense }\end{array}$ & $\begin{array}{l}\text { 5'-CGG-AAG-GTC-CCT-CAG-ACA-TC-3' } \\
\text { 5'-TCA-TGA-AGT-CGA-CAG-CTT-CCG-3' }\end{array}$ \\
\hline $\mathrm{p} 27$ & $\begin{array}{l}\text { Sense } \\
\text { Antisense }\end{array}$ & $\begin{array}{l}\text { 5'-AAG-CAC-TGC-CGG-GAT-ATG-GA-3' } \\
\text { 5'-AAC-CCA-GCC-TGA-TTG-TCT-GAC-3' }\end{array}$ \\
\hline COX-1 & $\begin{array}{l}\text { Sense } \\
\text { Antisense }\end{array}$ & $\begin{array}{l}\text { 5'-TGC-CCA-GCT-CCT-GGC-CCG-CCG-CTT-3' } \\
\text { 5'-GTG-CAT-CAA-CAC-AGG-CGC-CTC-TTC-3' }\end{array}$ \\
\hline $\mathrm{COX}-2$ & $\begin{array}{l}\text { Sense } \\
\text { Antisense }\end{array}$ & $\begin{array}{l}\text { 5'-TTC-AAA-TGA-GAT-TGT-GGG-AAA-AT-3' } \\
\text { 5'-AGA-TCA-TCT-CTG-CCT-GAG-TAT-CTT-3 }\end{array}$ \\
\hline GAPDH & $\begin{array}{l}\text { Sense } \\
\text { Antisense }\end{array}$ & $\begin{array}{l}\text { 5'-CGG-AGT-CAA-CGG-ATT-TGG-TCG-TAT-3' } \\
\text { 5'-AGC-CTT-CTC-CAT-GGT-GGT-GAA-GAC-3' }\end{array}$ \\
\hline
\end{tabular}

and necrosis) by inhibition of signal cascades involving cell survival (depending upon the cell type), thereby acting as an anti-proliferative agent in a variety of tumor cells (8-12). In addition to the inhibition of cell proliferation and increased apoptosis, many mechanisms have been proposed to explain the anti-carcinogenic effect of curcumin (13-15). However, the molecular mechanisms of curcumin in malignant cells are not yet clearly understood.

In this study, we investigated the effect of curcumin on the growth inhibition in human bladder carcinoma T24 cells. Moreover, the effects of this compound were tested on the activity of COXs and production of prostaglandin $\mathrm{E}_{2}\left(\mathrm{PGE}_{2}\right)$. The results demonstrated that curcumin treatment resulted in the arrest of the G2/M checkpoint of the cell cycle, which was related to down-regulating the intracellular levels of cyclin A and up-regulating the cyclin-dependent kinase (Cdk) inhibitor p21. Furthermore, down-regulation of COX-2 expression by curcumin treatment was associated with an inhibition of $\mathrm{PGE}_{2}$ release.

\section{Materials and methods}

Cell culture, curcumin and growth study. T24 cells were purchased from the American Type Culture Collection (Rockville, MD) and maintained in RPMI-1640 medium supplemented with $10 \%$ FBS, penicillin, and streptomycin. Curcumin [1,7-bis(4-hydroxy-3-methoxyphenyl)-1,6- heptadiene-3,5-dione, diferuloyl methane; Sigma Chemical Co., St. Louis, MO] was prepared as a $20 \mathrm{mM}$ solution in dimethyl sulfoxide and then further diluted in cell culture medium. Measurement of cell proliferation was determined using the 3-(4,5-dimethylthiazol-2-yl)-2,5-diphenyltetrazolium bromide (MTT) assay, which is based on the conversion of MTT to MTT-formazan via the mitochondria. For morphological study, cells were treated with curcumin for $48 \mathrm{~h}$ and directly photographed using an inverted microscope.

Flow cytometric analysis. After treatment with curcumin, cells were trypsinized, washed with phosphate-buffered saline (PBS), and fixed in $75 \%$ ethanol at $4^{\circ} \mathrm{C}$ for $30 \mathrm{~min}$. Prior to analyses, cells were again washed with PBS, suspended in cold propidium iodide (PI; Sigma) solution, and incubated at room temperature in the dark for $30 \mathrm{~min}$. Flow cytometric analyses were performed using a FACScan flow cytometry system (Becton-Dickinson, San Jose, CA).

RNA extraction and reverse transcription-PCR. Total RNA was isolated, and single-strand cDNA was synthesized from $2 \mu \mathrm{g}$ of total RNA using M-MLV reverse transcriptase (Gibco BRL, Gaithersburg, MD). The mRNAs were amplified by polymerase chain reaction (PCR) using the primers in Table I. Conditions for PCR reaction were: 1 cycle at $94^{\circ} \mathrm{C}$ for $3 \mathrm{~min}$; 35 cycles at $94^{\circ} \mathrm{C}$ for $45 \mathrm{sec}, 58^{\circ} \mathrm{C}$ for $45 \mathrm{sec}$ and $72^{\circ} \mathrm{C}$ for $1 \mathrm{~min}$; and 1 cycle at $72^{\circ} \mathrm{C}$ for $10 \mathrm{~min}$. Amplification products 
A)

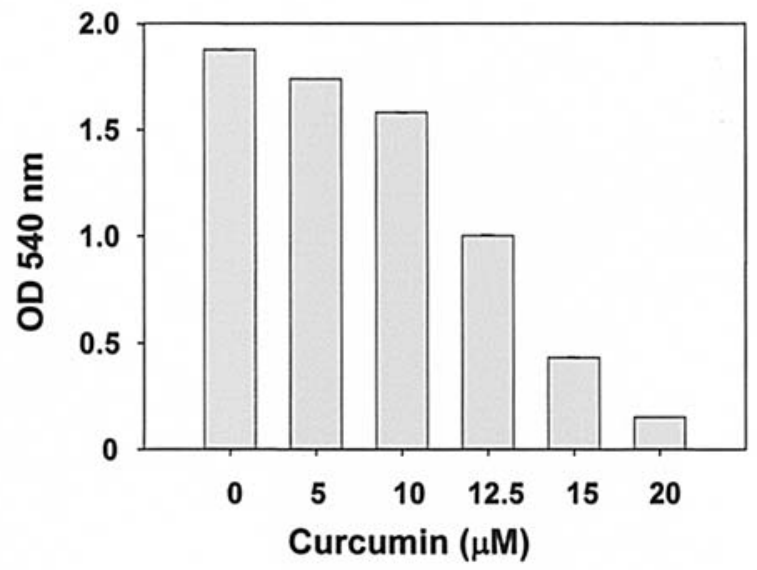

B)

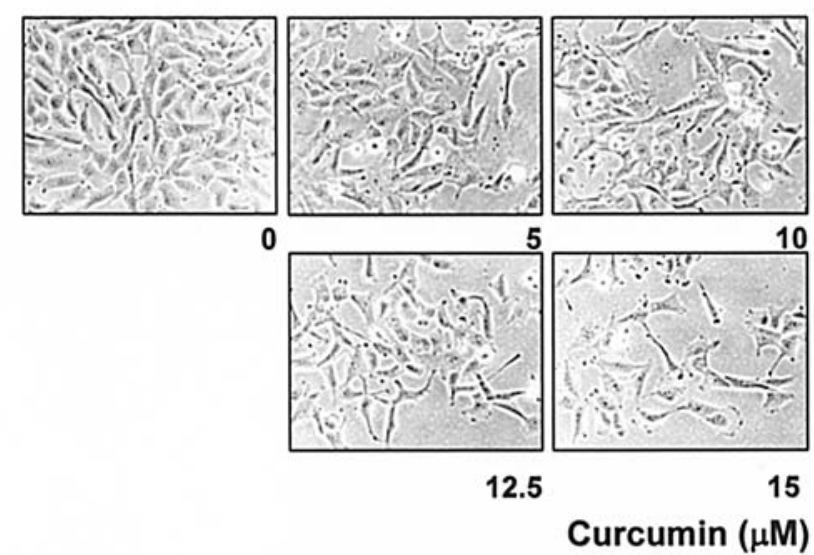

\section{C)}

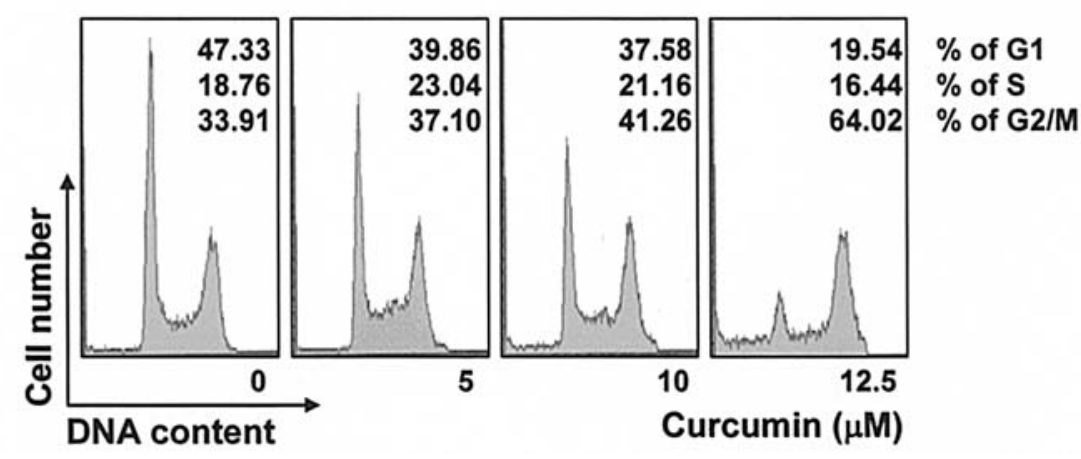

Figure 1. Growth inhibition, morphological changes and G2/M arrest by curcumin treatment in T24 cells. (A) Cells were plated at $4 \times 10^{4}$ cells per 60 -mm plate, and incubated for $24 \mathrm{~h}$. The cells were treated with variable concentrations of curcumin for $48 \mathrm{~h}$ and growth inhibition was measured by the metabolicdye-based MTT assay. Data are the mean of two different experiments. (B) After incubation with curcumin for $48 \mathrm{~h}$, the cells were examined under light microscopy. The data are representative examples for duplicate tests. Original magnification, x200. (C) Exponentially growing cells were treated with different concentrations of curcumin for $48 \mathrm{~h}$, then analyzed by flow cytometry as described in Materials and methods. The data are representative examples for duplicate tests. Data are the mean of two different experiments.

obtained by PCR were electrophoretically separated on $1 \%$ agarose gel and visualized by ethidium bromide (EtBr; Sigma) staining.

Gel electrophoresis and Western blot analysis. Western blot analysis was performed as described (16). Briefly, an equal amount of protein was subjected to electrophoresis on SDSpolyacrylamide gels and transferred to nitrocellulose membranes. Blots were probed with the desired antibodies for $1 \mathrm{~h}$, incubated with diluted enzyme-linked secondary antibody and then visualized using enhanced chemiluminescence (ECL) according to the recommended procedure (Amersham Corp., Arlington Heights, IL). Antibodies were purchased from Santa Cruz Biotechnology Inc. (Santa Cruz, CA) and Calbiochem (Cambridge, MA). Peroxidase-labeled donkey anti-rabbit immunoglobulin and peroxidase-labeled sheep antimouse immunoglobulin were purchased from Amersham.

$P G E_{2}$ EIA analysis. After treatment with curcumin, the medium was removed, and the $\mathrm{PGE}_{2}$ release by cells was measured. To measure $\mathrm{PGE}_{2}$ accumulation, enzyme immunoassay (EIA) was performed using a commercial kit (Cayman Chemicals, Ann Arbor, MI) according to the manufacturer's protocol. $\mathrm{PGE}_{2}$ production was normalized with respect to the number of viable cells present in the particular culture.

\section{Results}

Growth inhibition and morphological changes by curcumin. To evaluate the effects of curcumin on cell proliferation, we initially determined the effect of curcumin on the growth of T24 cells. As shown in Fig. 1A, curcumin had a strong inhibitory effect on cell proliferation in a dose-dependent manner, which was associated with a distinct morphological change (Fig. 1B).

Induction of G2/M arrest by curcumin. To determine whether curcumin treatment of cells resulted in the alteration of cell cycle progression, the cell cycle patterns of the T24 cel1s were examined. Analysis of the cell cycle distribution of cells after exposure to curcumin showed that these cells accumulated in the G2/M phase of the cell cycle (Fig. 1C). This was accompanied by a significant decrease in the G1 phase when compared with the untreated control cells, which suggested that the growth inhibitory effect of curcumin in T24 cells was the result of a block during the $\mathrm{G} 2 / \mathrm{M}$ phase.

Inhibition of cyclin A expression by curcumin. Since curcumin arrested T24 cells in the G2/M phase of the cell cycle, we determined the expression levels of cell cycle regulating factors at the G2/M boundary by RT-PCR and/or Western 


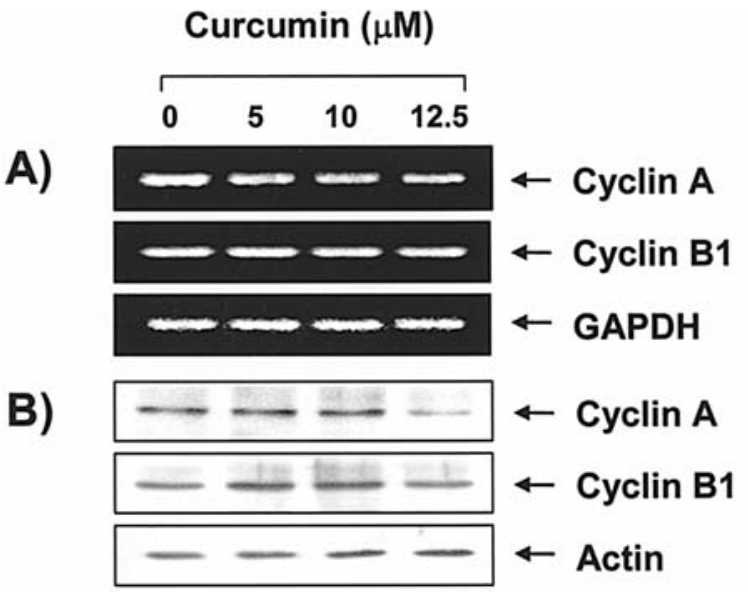

Figure 2. Inhibition of cyclin A by curcumin treatment in T24 cells. (A) Cells were cultured for $48 \mathrm{~h}$ in the absence $(0)$ or presence of curcumin (5.012.5 $\mu \mathrm{M}$ ), and total RNAs were isolated and reverse-transcribed. The resulting cDNAs were subjected to PCR with cyclin A and cyclin B1 primers and the reaction products were subjected to electrophoresis in $1 \%$ agarose gels and then visualized by EtBr staining. GAPDH was used as an internal control. (B) After 48-h incubation with curcumin, the cells were lysed and cellular proteins were separated by $10 \%$ SDS-polyacrylamide gels, then transferred onto nitrocellulose membranes. The membranes were probed with antibodies against cyclin A and cyclin B1. Proteins were visualized using an ECL detection system. Actin was used as an internal control.

\section{Curcumin $(\mu \mathrm{M})$}

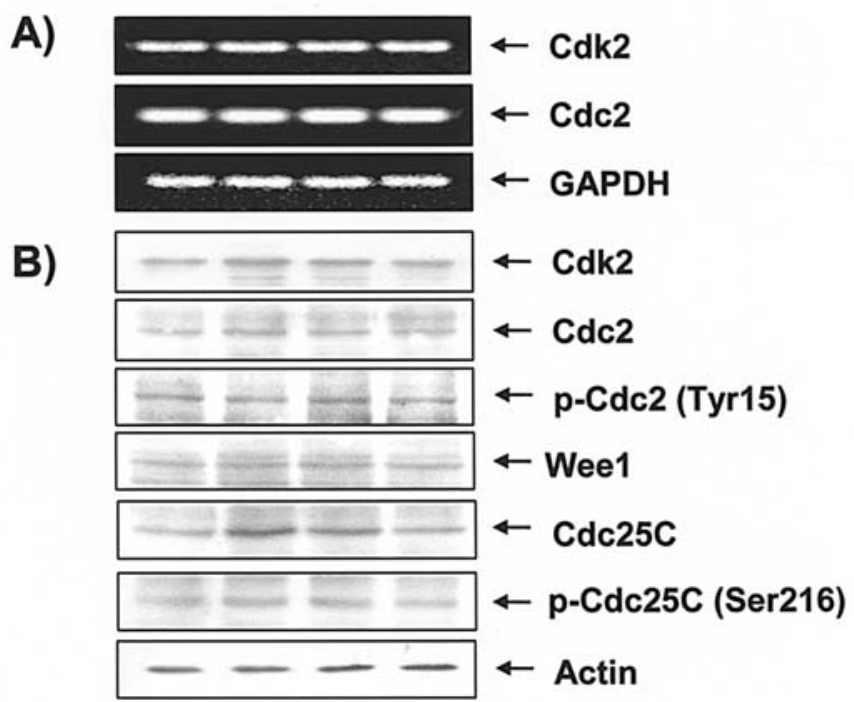

Figure 3. Effect of curcumin on cellular Cdks, Wee1 and Cdc25C expression in T24 cells. (A) Cells were incubated with variable concentrations of curcumin. After incubation for $48 \mathrm{~h}$, total RNAs were isolated and reversetranscribed. The resulting cDNAs were subjected to PCR with Cdk2 and $\mathrm{Cdc} 2$ primers, and the reaction products were subjected to electrophoresis in $1 \%$ agarose gels and visualized by EtBr staining. GAPDH was used as an internal control. (B and C) Cells were lysed and equal proteins were resolved on $10 \%$ SDS-polyacrylamide gels, then transferred onto nitrocellulose membranes. Western blots were detected with the indicated antibodies and ECL. Actin was used as an internal control.

blot analysis (Figs. 2 and 3). The protein and mRNA levels of cyclin A were gradually decreased by curcumin treatment, but the levels of cyclin B1, Cdc2, Cdk2, Wee1 and Cdc25C

\section{Curcumin $(\mu \mathrm{M})$}

A)

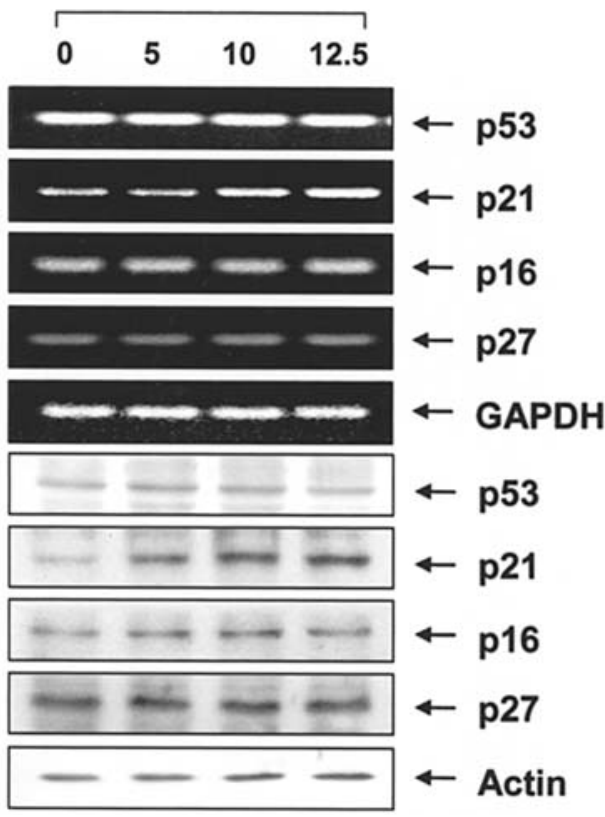

Figure 4. Induction of Cdk inhibitor $\mathrm{p} 21$ by curcumin treatment in T24 cells. (A) Cells were cultured for $48 \mathrm{~h}$ in the absence or in the presence of curcumin and total RNAs were isolated and reverse-transcribed. The resulting cDNAs were subjected to PCR with indicated primers and the reaction products were subjected to electrophoresis in $1 \%$ agarose gels and visualized by EtBr staining. GAPDH was used as an internal control. (B) After $48 \mathrm{~h}$ incubation with curcumin, the cells were lysed and then cellular proteins were separated by $10 \%$ SDS-polyacrylamide gels and transferred onto nitrocellulose membranes. The membranes were probed with the indicated antibodies. Proteins were visualized using an ECL detection system. Actin was used as an internal control.

and the phosphorylation states of Cdc2 and Cdc25C proteins were unchanged. These results suggest that the suppressive effects of curcumin on the growth of T24 cells are partly caused by down-regulating the levels of cyclin A.

Induction of Cdk inhibitor p21 by curcumin. Cdk inhibitors are known to interfere with cell cycle progression and cause phase-specific cycle arrest. These kinase inhibitors perturb the phosphorylation process by directly interacting with their target proteins, i.e. cyclins or Cdks. We examined the possible up-regulation of $\mathrm{Cdk}$ inhibitors in cells treated with curcumin. Our results showed that curcumin treatment increased the expression level of p21 and its mRNA in a dosedependent manner (Fig. 4). However, it did not significantly affect other Cdk inhibitors, such as p16 and p27. Because the levels of tumor suppressor p53 were not induced by curcumin, it is likely that the induction of p21 is mediated through a p53-independent pathway.

Inhibition of COX-2 activity and $P G E_{2}$ production by curcumin . We next determined whether the curcumin-induced antiproliferative effect of T24 cells was connected to reduced activity of COXs. RT-PCR and Western blot analyses showed a significant decrease in COX-2 mRNA and protein expression over time after curcumin treatment, but curcumin was ineffective regarding COX-1 expression (Fig. 5A and B). To confirm that $\mathrm{PGE}_{2}$ production was associated with the 
A)

Curcumin $(\mu \mathrm{M})$
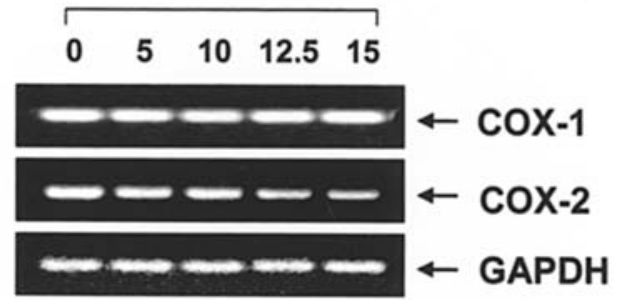

B)

\section{Curcumin $(\mu \mathrm{M})$}

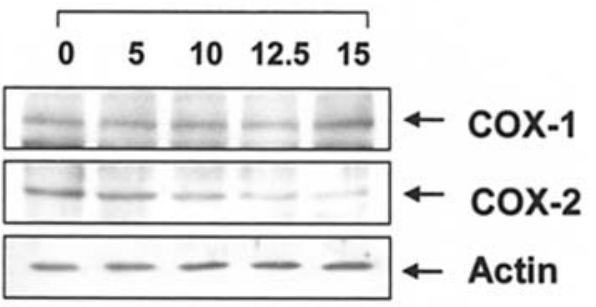

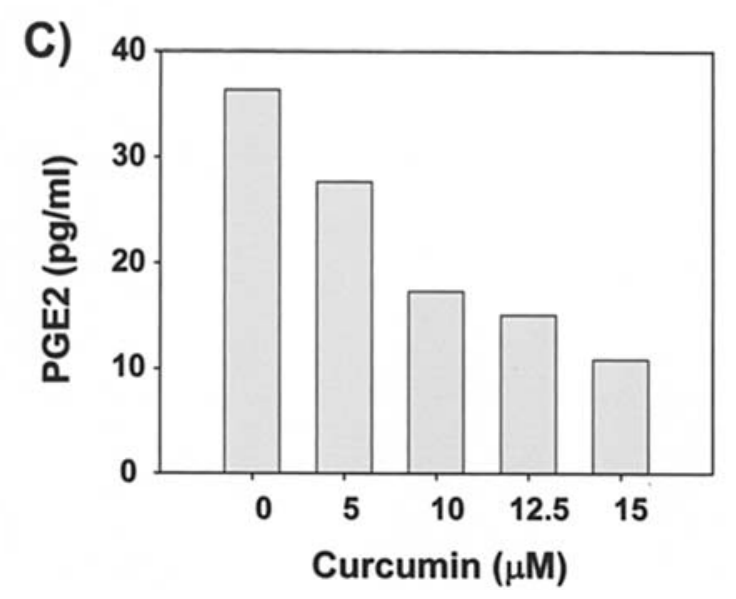

Figure 5. Inhibition of COX-2 expression and $\mathrm{PGE}_{2}$ production in T24 cells after exposure to curcumin. (A) After 48-h incubation with curcumin, total RNAs were isolated and reverse-transcribed. The resulting CDNAs were subjected to PCR with COX-1 and COX-2 primers and the reaction products were subjected to electrophoresis in a $1 \%$ agarose gel and visualized by EtBr staining. GAPDH was used as an internal control. (B) Cells were treated with the indicated concentrations of curcumin for $48 \mathrm{~h}$ and collected. The cells were lysed and cellular proteins were separated by $10 \%$ SDS-polyacrylamide gels. Proteins were visualized by Western blotting using anti-COX-1 and anti-COX-2 antibodies, and ECL detection. Actin was used as an internal control. (C) Cells were treated

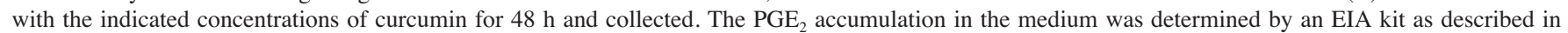
Materials and methods. Data represent the relative mean values of two independent experiments.

catalytic activity of COX-2, cells were cultured in the absence or presence of curcumin, and $\mathrm{PGE}_{2}$ levels were measured. As shown in Fig. 5C, the synthesis of $\mathrm{PGE}_{2}$ was concentrationdependent and this production was significantly decreased over time after curcumin treatment, which correlated with the down-regulation of COX-2 expression.

\section{Discussion}

In terms of cell cycle regulation, Cdks play a most critical role. Two major mechanisms for $\mathrm{Cdk}$ regulation are the binding with its catalytic subunit cyclin followed by activation of Cdk/cyclin complexes and the binding with Cdk inhibitors followed by inactivation of $\mathrm{Cdk} /$ cyclin complexes (3). An alteration in the formation of these complexes could lead to increased cell growth and proliferation and decreased cell growth and proliferation followed by differentiation and/or cell death by apoptosis (2). Cyclin A, which interacts with $\mathrm{Cdk} 2$, has been found to play an important role in the regulation of phases $S$ and G2/M (17). The ultimate target of the $\mathrm{G} 2 / \mathrm{M}$ checkpoint signaling pathway is $\mathrm{Cdc} 2 /$ cyclin $\mathrm{B} 1$. $\mathrm{Cdc} 2$ forms a heterodimeric complex with cyclin B1, which is maintained in an inactive form by phosphorylation of residues Thr14 and Tyr15 in the ATP-binding domain of Cdc2 by Wee1 kinase (18) and converted to an active form by dephosphorylation of these residues by phosphatase Cdc25C (19). This dephosphorylation/activation is an absolute requirement for the onset of mitosis. It has been shown that Cdc25C is negatively regulated by phosphorylation of its Ser216 residue during interphase or in response to DNA damage or incomplete DNA replication (20). In this study, flow cytometric analysis clearly revealed that human bladder carcinoma T24 cells were arrested by curcumin at the G2/M phase of the cell cycle (Fig. 1), as observed in several cell lines (8-10). Results from RT-PCR and immunoblotting analyses demonstrated that curcumin inhibited both the mRNA and intracellular protein levels of cyclin A but not cyclin B1 in T24 cells in a concentration-dependent manner (Fig. 2). However, the expression of $\mathrm{Cdc} 2$ and Wee1 kinase protein and the levels of phospho-Cdc2 at Tyr15 remained unchanged in curcumin-treated cells. Curcumin also did not affect the levels of Cdc25C protein or the phosphorylation of Cdc25C at Ser216 in T24 cells (Fig. 3). The results suggest that the induction of phosphorylation of $\mathrm{Cdc} 2$ and $\mathrm{Cdc} 25 \mathrm{C}$ is not a universal feature of the curcumin-induced G2/M arrest of the cell cycle in T24 cells.

The activity of Cdks is negatively regulated by binding to Cdk inhibitors in response to a variety of anti-proliferative 
signals. Of several Cdk inhibitors, p21, the archetypal member of this family that was isolated as a Cdk2-associated protein and an inhibitor of $\mathrm{Cdk} 2$, is an important mediator of cell cycle arrest imposed by tumor suppressor $\mathrm{p} 53$ in response to DNA damage (21). It was shown that a novel form of p21 protein can inhibit growth by acting not at G1, but at G2/M $(22,23)$. In addition to being induced by p53, p 21 is also induced by other factors in a p53-independent pathway $(24,25)$. Additional studies have demonstrated that relative levels of p21 may be critical in determining the threshold kinase activity of various $\mathrm{Cdk} /$ cyclin complexes suggesting that appropriate levels of p21 may be critical in the regulation of cell growth $(3,26,27)$. The present results clearly indicated that curcumin enhanced the expression of Cdk inhibitor p21, but not p16 and p27 at both the transcriptional and translational level without altering the p53 expression (Fig. 4). Therefore, the induction of p21 and G2/M arrest by curcumin in T24 cells may be regarded as p53-independent events, which is in agreement with other reports $(10,28)$.

Epidemiological observations and laboratory research have suggested that non-steroidal anti-inflammatory drugs (NSAIDs) reduce the risk of cancer and the inhibition of carcinogenesis by NSAIDs is mediated through the modulation of prostaglandin production from the substrate arachidonic acid by rate-limiting enzymes known as COXs. Two isoforms of COXs have been identified: COX-1, which is considered to be the constitutively expressed form and thought to serve housekeeping functions; and COX-2, which is expressed at very low basal levels and rapidly induced by different products, such as tumor promoters, growth factors or inflammatory cytokines (4). Thus, COX-2 up-regulation is a key step in carcinogenesis, and inhibition of COX-2 activity promises to be an effective approach in the prevention and treatment of cancer (5). Lee et al demonstrated that curcumin inhibits the interferon (IFN)- $\alpha$-induced expression of COX-2 (29). The suppression of IFN- $\alpha$-induced COX-2 activation by curcumin is consistent with a previous study, which showed that the tumor necrosis factor- $\alpha$-induced COX-2 expression in human colon cancer cells was inhibited by curcumin via $\mathrm{NF}-\kappa \mathrm{B}$ activation (30). Zhang et al also reported that treatment of several human gastrointestinal cell lines with curcumin suppressed the expression of COX-2 protein and mRNA and $\mathrm{PGE}_{2}$ production by chenodeoxycholate or phorbol ester (31). To further elucidate the mechanisms by which curcumin inhibits T24 cell proliferation, we investigated whether the curcumin-induced growth inhibitory effect of T24 cells was associated with an inhibition of basal COX-2 expression and activity. As shown in Fig. 5, curcumin treatment downregulated both the mRNA and protein expression of COX-2 and inhibited the production of $\mathrm{PGE}_{2}$ in a concentrationdependent manner. The data suggested that the inhibition of COX-2 expression and $\mathrm{PGE}_{2}$ production is consistent with the anti-proliferative effect of curcumin in T24 cells.

In conclusion, our present findings indicated that curcumin potently suppresses the growth of T24 human bladder carcinoma cells by the induction of $\mathrm{G} 2 / \mathrm{M}$ arrest of the cell cycle through the inhibition of cyclin $\mathrm{A}$ and induction of $\mathrm{Cdk}$ inhibitor p21, and concomitantly causes a loss of $\mathrm{PGE}_{2}$ by decreasing COX-2 expression. Although further studies are needed, these results suggest that the induction of p21 and loss of COX-2 activity may be good surrogate biomarkers for assessing the anti-tumor activity of curcumin.

\section{Acknowledgements}

This research was supported by the Korea Science and Engineering Foundation through the National Research Laboratory Program grant M10500000008-05J000000810.

\section{References}

1. Abraham RT: Cell cycle checkpoint signaling through the ATM and ATR kinases. Genes Dev 15: 2177-2196, 2001

2. Cheng T: Cell cycle inhibitors in normal and tumor stem cells. Oncogene 23: 7256-7266, 2004.

3. Lee MH and Yang HY: Negative regulators of cyclin-dependent kinases and their roles in cancers. Cell Mol Life Sci 58: 1907-1922, 2001

4. Soh JW and Weinstein IB: Role of COX-independent targets of NSAIDs and related compounds in cancer prevention and treatment. Prog Exp Tumor Res 37: 261-285, 2003.

5. Umar A, Viner JL, Anderson WF and Hawk ET: Development of COX inhibitors in cancer prevention and therapy. Am J Clin Oncol 26: S48-S57, 2003.

6. Aggarwal BB, Kumar A and Bharti AC: Anticancer potential of curcumin: preclinical and clinical studies. Anticancer Res 23: 363-398, 2003.

7. Duvoix A, Blasius R, Delhalle S, Schnekenburger M, Morceau F, Henry E, Dicato M and Diederich M: Chemopreventive and therapeutic effects of curcumin. Cancer Lett 223: 181-190, 2005.

8. Chen H, Zhang ZS, Zhang YL and Zhou DY: Curcumin inhibits cell proliferation by interfering with the cell cycle and inducing apoptosis in colon carcinoma cells. Anticancer Res 19: 3675-3680, 1999.

9. Moragoda L, Jaszewski R and Majumdar AP: Curcumin induced modulation of cell cycle and apoptosis in gastric and colon cancer cells. Anticancer Res 21: 873-878, 2001

10. Choudhuri T, Pal S, Das T and Sa G: Curcumin selectively induces apoptosis in deregulated cyclin D1-expressed cells at G2 phase of cell cycle in a p53-dependent manner. J Biol Chem 280: 20059-20068, 2005.

11. Mukhopadhyay A, Banerjee S, Stafford LJ, Xia C, Liu M and Aggarwal BB: Curcumin-induced suppression of cell proliferation correlates with down-regulation of cyclin D1 expression and CDK4-mediated retinoblastoma protein phosphorylation. Oncogene 21: 8852-8861, 2002.

12. Deeb D, Xu YX, Jiang H, Gao X, Janakiraman N, Chapman RA and Gautam SC: Curcumin (Diferuloyl-Methane) enhances tumor necrosis factor-related apoptosis-inducing ligand-induced apoptosis in LNCaP prostate cancer cells. Mol Cancer Ther 2: 95-103, 2003

13. Lin JK, Pan MH and Lin-Shiau SY: Recent studies on the biofunctions and biotransformations of curcumin. Biofactors 13: 153-158, 2000.

14. Leu TH and Maa MC: The molecular mechanisms for the antitumorigenic effect of curcumin. Curr Med Chem Anti-Cancer Agents 2: 357-370, 2002.

15. Gescher A: Polyphenolic phytochemicals versus non-steroidal anti-inflammatory drugs: which are better cancer chemopreventive agents? J Chemother 16: S3-S6, 2004.

16. Choi YH, Lee SJ, Nguyen P, Jang JS, Lee J, Wu ML, Takano E, Maki M, Henkart PA and Trepel JB: Regulation of cyclin D1 by calpain protease. J Biol Chem 272: 28479-28484, 1997.

17. Ling YH, el-Naggar AK, Priebe W and Perez-Soler R: Cell cycle-dependent cytotoxicity, G2/M phase arrest, and disruption of p34cdc2/cyclin B1 activity induced by doxorubicin in synchronized P388 cells. Mol Pharmacol 49: 832-841, 1996.

18. McGowan CH and Russell P: Human Wee1 kinase inhibits cell division by phosphorylating p34cdc2 exclusively on Tyr 15 . EMBO J 12: 75-85, 1993

19. Jin P, Gu Y and Morgan DO: Role of inhibitory CDC2 phosphorylation in radiation-induced G2 arrest in human cells. J Cell Biol 134: 963-970, 1996.

20. Perdiguero E and Nebreda AR: Regulation of Cdc25C activity during the meiotic G2/M transition. Cell Cycle 3: 733-737, 2004 
21. El-Deiry WS, Tokino T, Velculesco VE, Levy DB, Parsons R, Trent JM, Lin D, Mercer EW, Kinzler KW and Vogelstain B: WAF1, a potential mediator of p53 suppression. Cell 75: 817-825, 1993.

22. Baus F, Gire V, Fisher D, Piette J and Dulic V: Permanent cell cycle exit in G2 phase after DNA damage in normal human fibroblasts. EMBO J 22: 3992-4002, 2003.

23. Dulic V, Stein GH, Far DF and Reed SI: Nuclear accumulation of p21Cip1 at the onset of mitosis: a role at the G2/M-phase transition. Mol Cell Biol 18: 546-557, 1998.

24. Zeng YX and El-Deiry WS: Regulation of $\mathrm{p} 21^{\mathrm{WAF} 1 / \mathrm{CIP} 1}$ expression by p53-independent pathways. Oncogene 12: 1557-1564, 1996.

25. Zhang W, Grasso L, McClain CD, Gambel AM, Cha Y, Travali S, Deisseroth $\mathrm{AB}$ and Mercer WE: p53-independent induction of WAF1/CIP1 in human leukemia cells is correlated with growth arrest accompanying monocyte/marcrophage differentiation. Cancer Res 55: 668-674, 1995.

26. Xiong Y, Hannon G, Zhang H, Casso D, Kobayashi R and Beach D: p21 is a universal inhibitor of cyclin kinases. Nature 366: 701-704, 1993.
27. Elledges SJ and Harper JW: Cdk inhibitor: on the threshold of checkpoints and development. Curr Opin Cell Biol 6: 847-852, 1994.

28. Hour T, Chen J, Huang CY, Guan JY, Lu SH and Pu YS: Curcumin enhances cytotoxicity of chemotherapeutic agents in prostate cancer cells by inducing p21(WAF1/CIP1) and C/EBP beta expressions and suppressing NF-kappaB activation. Prostate 51: $211-218,2002$.

29. Lee J, Im YH, Jung HH, Kim JH, Park JO, Kim K, Kim WS, Ahn JS, Jung CW, Park YS, Kang WK and Park K: Curcumin inhibits interferon-alpha induced NF-kappaB and COX-2 in human A549 non-small cell lung cancer cells. Biochem Biophys Res Commun 334: 313-318, 2005.

30. Plummer S, Holloway K, Manson M, Munks R, Kaptein A, Farrow S and Howells L: Inhibition of cyclo-oxygenase 2 expression in colon cells by the chemopreventive agent curcumin involves inhibition of NF- $\mathrm{KB}$ activation via the NIK/IKK signaling complex, Oncogene 18: 6013-6020, 1999.

31. Zhang F, Altorki NK, Mestre JR, Subbaramaiah K and Dannenberg AJ: Curcumin inhibits cyclooxygenase-2 transcription in bile acid- and phorbol ester-treated human gastrointestinal epithelial cells. Carcinogenesis 20: 445-451, 1999. 